\title{
大腸の早期癌の検討
}

\begin{tabular}{|c|c|c|c|c|c|}
\hline \multicolumn{6}{|c|}{ 東京医科歯科大学第 1 外科 } \\
\hline & 慶太 & 岡部 & 聡 & 中島 & 和美 \\
\hline & 昌之 & 若山 & 宏 & 高相 & \\
\hline & 慶虎 & 竹村 & 克二 & 遠藤 & $6 夫$ \\
\hline
\end{tabular}

\section{A STUDY ON EARLY CANCER OF THE COLON AND RECTUM}

\author{
Keita ISHII, Satoshi OKABE, Kazumi NAKAJIMA, \\ Masayuki ANDO, Hiroshi WAKAYAMA, Koh Sang Jin, \\ Yoshitora KANEKo, Katsuji TAKEMURA and Mitsuo ENDO
}

The First Department of Surgery, Tokyo Medical and Dental University, School of Medicine

大腸 $\mathrm{m} \cdot \mathrm{sm}$ 癌 49 例 $(\mathrm{m}$ 癌 27 病巣, $\mathrm{sm}$ 癌 23 病巣) の肉眼型と深達度, 腫瘍内に占める癌の大きさと深 達度,および治療について検討を行った，Ip, Isp, Is の30〜40\%, IIa の $50 \%$, IIa +IIcなどの複合型 の $100 \%$ が sm 癌であった. $2 \mathrm{~cm}$ 以上の癌の $60 \%$ (11例) が $\mathrm{sm}, 40 \%$ （7例）が $\mathrm{m}$ で, 大きさと深達 度の相関は認めなかった，癌でリンパ節転移を認めた例はなく, 癌の遺残さえ起こさなければ polypectomy むしくは経肛門的腫瘍切除などで十分根治性が得られた. sm 癌でリンパ節の病理学的 検索を行えた20例中 2 例 (10\%)に壁在りンパ節の転移を認めた。したがって sm 癌では根治性の面か ら $\mathrm{R}_{\mathbf{2}}$ のリンパ節郭清を伴う手術が望をれた。

索引用語 : 大腸 $\mathrm{sm}$ 癌のリンパ節転移, 大腸早期癌の治療

はじめに

大腸癌取扱い規約1では早期癌"2を定義していない が，最近は胃癌と同様に癌浸潤が sm までのものを早 期癌とする傾向が一般的である，ま大大腸 $\mathrm{m} ・ \mathrm{sm}$ 癌は 近年䛦断技術の向上や社会的関心の高まりにより増加 しつつある.治療については，m癌ならば現在までに リンパ節転移例はなく極めて限局した切除で十分根治 性が得られるため可能な限り major operation を避け るというのが一致した見解といえる. Shathey ら ${ }^{314)} は$ 有茥性大腸癌のリンパ節転移例を経験し，これよりリ ンパ節侵襲陽性, 未分化型癌, 茎が極端に短いか茥の 根部をで癌が拡がりを示した場合を polypectomyの 除外条件と述べている。一方, 大腸癌取扱い規約では 原則として sm 癌は郭清を伴う major operation を行 らとして, polypectomy 後の sm 癌にさらに追加手術 を行らか否かの目安として, Shatney らと同様の内容

$<1986$ 年 2 月 12 日受理 $>$ 別刷請求先 : 石井 度太 T113 文京区湯島 1-5-45 東京医科歯科大学第 1 外科
の基準を設けこれに従うとしている. sm 癌で major operationを施行することの問題点として, ひとつは 大腸 $\mathrm{Sm}$ 癌のリンパ節転移率が $3 \sim 8 \%$ と低く, 大部 分の患者が polypectomy 後不必要な追加手術を受け る結果となること，もらひとつは特に直腸癌の場合 major opration が肛門機能障害拈よび泌尿・生殖機能 障害を引き起こす危険性が高く，根治性を得るために 衰失する代価が高すぎることである。

本論文ではリンパ節転移を呈した 2 例の $\mathrm{sm}$ 癌の肉 眼的および組織学的病理所見を検討し，また文献的に リンパ節転移陽性の sm 癌の所見と比較した。これに よりリンパ節転移を示唆する傾向が原発の菙湯に認め られ，それらが追加手術の指標となり適切な治療が成 し遂げられるかといら観点から考察を行った。

対 象

1975年から1985年までに当科扣よび当科関連施設で 手術または polypectomyを行った大腸癌のらち, 進行 癌に合併した症例を除外した深達度 $\mathrm{m} \cdot \mathrm{sm}$ の大腸癌 49例，50病巣を対象とした。これは同時期の大腸癌 554 
表 1 大腸癌全体の年齢分布と大腸 $\mathrm{m} \cdot \mathrm{sm}$ 癌の年齢 分布

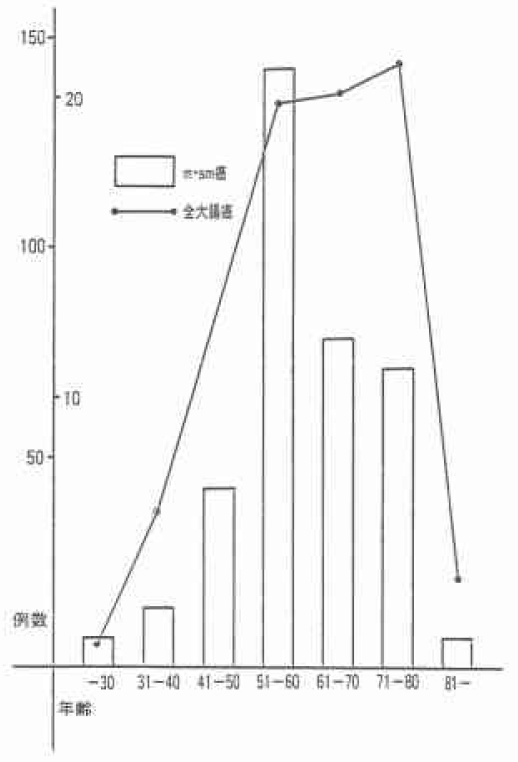

図 1 大腸 $\mathrm{m} \cdot \mathrm{sm}$ 癌の占居部位

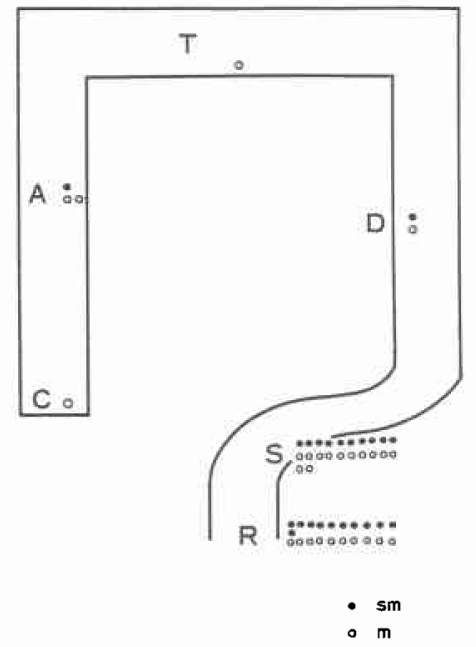

例の8.8\%にあたる.内訳は $\mathrm{m}$ 癌26例(らち 1 例は多発 癌), $\mathrm{sm}$ 癌23例で男性32例，女性17例で平均年齢は 50.6 歳で51 60歳の年齢層が21例と最も多く, 全大腸 癌の年齢分布より10歳若年側にピークを示した（表 1).

1. 占居部位

\section{結 果}

図 1のよ5にS 状結腸（S）：22例，直腸（R）：21
例と両者で全体の $86 \%$ を占め, 全大腸癌の $\mathrm{S}: 169$ 例 (30.5\%)，R：240例（43.3\%）に比べ遠位大腸に高頻 度に認められた。盲腸 (C), 上行結腸 (A), 横行結 腸（T）など近位大腸に早期癌の頻度が低いのは肚門 より遠隔な部位ほど症状が出現しにくいためと思われ る.

\section{2. 初発症状}

下血，血便などの出現を主訴とするものが36例 (73\%) と最も多かった。出血は進行癌でも同じように 重要な症状であるが，この中には偶然併存した内痔核 などの肛門病変よりの出血で，精査を行って発見され た症例も数例含まれる。その他の症状として腹痛が 2 例，腹部膨満感が 2 例，下凩もしくは粘液の排泄が 4 例，また検診で 5 例発見されている。

\section{3. 肉眼型と深達度}

大腸癌取扱い規約では I 型の亜分類として有茎型を Ip，広基型を Is として 2 つに大別している，今回，内 視鏡的，レントゲン的に観察して腫瘍の位置が変わる ほど長い菱を持っているるのをIpとし，腫瘍は動かな いが腫瘍底部付近で深くくびれ込み，腫瘍と正常粘膜 の移行部が見えないものをIsp とした. Ip の39\%, Isp の36\%, Is の $33 \%$ が sm 癌で, この 3 者間で深達度と肉 眼型の関係は明らかでない. IIa は I 型より sm 癌の頻 度が $50 \%$ と高くなり，IIa+IIcなど癌進展に伴って複 雑な形態を取り始めると $100 \%$ が $\mathrm{sm}$ に浸潤する（表 2).ここでIp+IIc (図 2) は本来 Ip の癌であったと 思われるものが stalk invasion して，さらに stalkの 肛門側の正常粘膜まで浸潤しこの粘膜面で IIc を形成 したまれな症例である゙5. IIa+Is はIIa が集簇しその らちのひとつが高く成長し Is とせざるをえない形態 をとった 1 例である。これら IIa + IIc, Ip+IIc, IIa+Is

表 2 癌の肉眼型と深達度

\begin{tabular}{c|c|c}
\hline 肉眼 型 & 例 数 & $\begin{array}{c}\text { sm 癌の } \\
\text { 占める割合 }\end{array}$ \\
\hline Ip & 18 & $7 / 18(39)$ \\
\hline Isp & 14 & $5 / 14(36)$ \\
\hline Is & 6 & $2 / 6(33)$ \\
\hline Ia & 6 & $3 / 6(50)$ \\
\hline IIa+Ic & 4 & $4 / 4(100)$ \\
\hline Ip+IIc & 1 & $1 / 1(100)$ \\
\hline Ila +Is & 1 & $1 / 1(100)$ \\
\hline & &
\end{tabular}


図 2 HE 染色, ルーペ像Ipの stalk invasionを示 于.

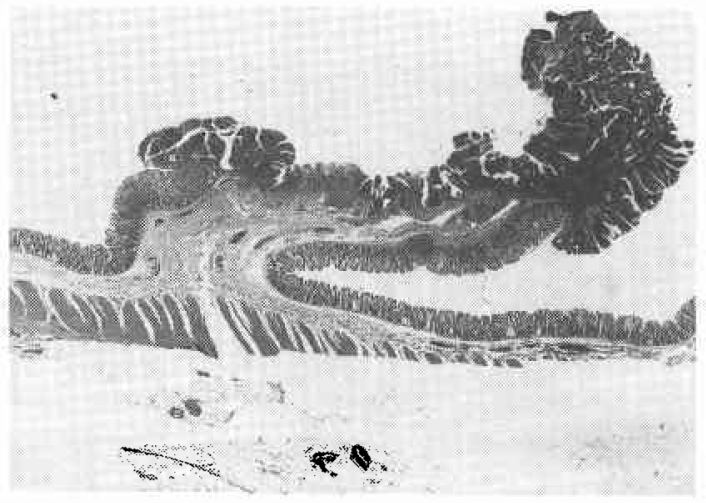

など複合型と呼べる形態では sm 癌の可能性は非常に 高くなる、また I 型（villous 型を除外する）の $\mathrm{sm}$ 癌 10 例中 6 例は，その頂部に陥凹を持ち同部で sm 浸潤 していた.

4. 大ささと深達度

癌の大きさはプレパラートを検鏡して，癌部分，腺 腫部分を同定し, 癌部分のみの円周を計測して求めた。 $2 \mathrm{~cm}$ 以上の大きい癌でも $40 \%$ は癌で，大きいものが sm癌とは言觉ないようである。京た れの大ささの癌が添湆均等に見られるのに対して, sm 癌では $2 \mathrm{~cm}$ 以上の大きい癌が11例と多いが, $0.5 \mathrm{~cm}$ 以 下の小さな癌も 4 例認められた（表 3).

5. 癌占有率と深達度

腫瘍全体が癌 (polypoid cancer)，一部に腺腫を認め る癌 (adenoma in cancer), 一部が癌 (cancer in adenoma）と 3 群に分けて，これらと深達度の関係を 検討した，polypoid cancer の40\%のm癌，60\%が sm 癌で前述の大きさと深達度の関係と汪涪同じ傾向を示 した。また cancer in adenoma の sm 癌が 6 例である のに対して, adenoma in cancer の sm 癌は 1 例と極 端に少なく,ここでは sm 癌の 2 極化傾向が認められ た（㤗 4 ).

6. 治療

m癌で major operation を施行した症例は16例ある が, このらち肉眼型が Ip もしくは Isp で尰廈も3cm 以 下と retrospective に見て polypectomy むしくは，経 肛門的腫瘍切除術が可能であった症例が 7 例存在し た， m癌で直腸切断術を施行した症例は 3 例はあり， これらは全例腫瘍が5cm 以上と大さいために深達度 sm 以上之術前診断し, 始めから major operationを
表 3 癌の大きさと深達度

\begin{tabular}{c|c|c|c}
\hline 深達度 & $\mathrm{m}$ & $\mathrm{sm}$ & 計 \\
\hline $2 \mathrm{~cm} \leqq$ & $7(39)$ & $11(61)$ & $18(100)$ \\
\hline $1=\sim 2 \mathrm{~cm}$ & $7(54)$ & $6(46)$ & $13(100)$ \\
\hline $0.5=\sim 1 \mathrm{~cm}$ & $5(83)$ & $1(17)$ & $6(100)$ \\
\hline $0.5 \mathrm{~cm}>$ & $7(64)$ & $4(36)$ & $11(100)$ \\
\hline & & \multicolumn{3}{c}{ ( )は\% }
\end{tabular}

表 4 腫瘍内の癌の占有率と深達度

\begin{tabular}{|c|c|c|c|}
\hline 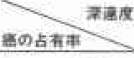 & $\mathrm{m}$ & sm & 偖 \\
\hline D $100 \%$ & $10(40)$ & $15(60)$ & $25(100)$ \\
\hline (1) $50 \% \leq$ & 8 (89) & $1(11)$ & $9(100)$ \\
\hline D $50 \%>$ & $8(57)$ & $6(43)$ & $14(100)$ \\
\hline
\end{tabular}

表 5 大腸 $\mathrm{m} \cdot \mathrm{sm}$ 癌の治療

\begin{tabular}{|c|c|c|}
\hline 消 & $\mathrm{m}$ & $\mathrm{sm}$ \\
\hline 郭 清 (十) の 切 除 & 15 & 14 \\
\hline 郭 清 (一) の 切 除 & 1 & 0 \\
\hline$\stackrel{\text { 腫 瘍 切 除 }}{\longrightarrow}$ 追加手術 & 1 & 6 \\
\hline $\begin{array}{l}\text { 腫瘍 切 除 } \\
\text { (ポベタド含む) }\end{array}$ & 10 & 3 \\
\hline
\end{tabular}

\begin{tabular}{|c|c|c|}
\hline & $\mathrm{m}$ & $\mathrm{sm}$ \\
\hline 直鹏切断術 & 3 & 4 \\
\hline 前方切除潹 & 3 & 4 \\
\hline 畽㾂切陈赫 & 4 & 3 \\
\hline \multicolumn{3}{|c|}{ 一秙 輊一 } \\
\hline & $\mathrm{m}$ & sm \\
\hline 腸 㧅除 術 & 10 & 12 \\
\hline$A \div y \propto b+z-$ & 6 & 0 \\
\hline
\end{tabular}

行った. sm 癌では polypectomy 後 major operation を追加したのは 6 例で，全例結腸癌であった．経肛門 的腫瘍切除術のみで外科治療を完了したのは 3 例で, 全例直腸癌で高齿を理由に追加手術を断念した（表 5 , 6 ). 


\section{7. 病理組織所見}

組織型は高分化腺癌（乳頭腺癌を含む）が46病巣, 中分化腺癌 4 病巣で低分化腺癌は 1 例も認められな かった. $\mathrm{sm}$ 癌23例中 $\mathrm{ly}(+)$ は 6 例， v (+) は 2 例 のみであったが，これらの脈管侵襲陽性例でリンパ節 転移例はなかった。

8. リンパ節転移例

リンパ節転移率は 20 例中 2 例，10\%であった， 1 例 は Rs に発生した $3.0 \mathrm{~cm}$ の villous adenoma の focal cancer を認めた cancer in adenoma で, 肉

\section{図 3 リンパ節転移陽性例の切除固定標本}

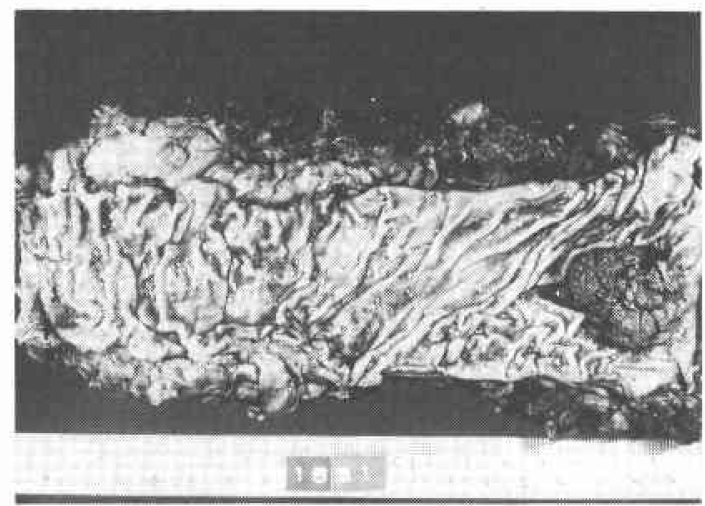

図 $4 \mathrm{HE}$ 染色, ルーへ像, 茎は左右に分枝し左側先端 部の癌を認める。

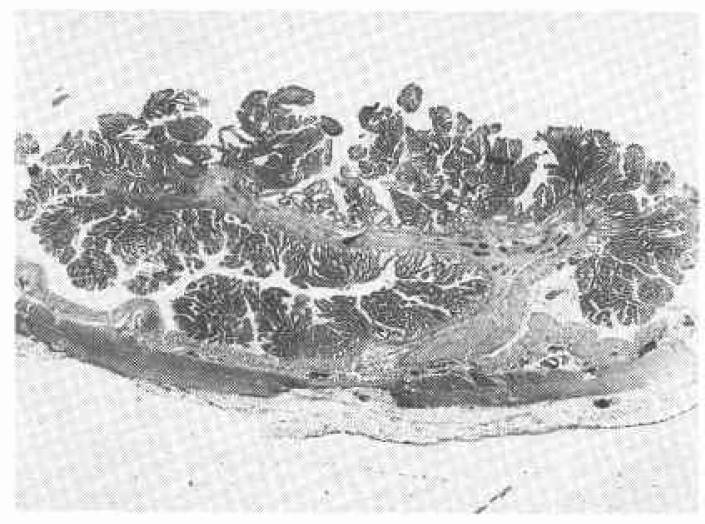

眼型は Isp, 組織型は高分化腺癌で，腫瘍の左右に伸び た茥の左側先端部にわずかな $\mathrm{sm}$ 浸潤をしていた（図 3，4). 低位前方切除術を施行し，郭清したリンパ節 3 個のうち 1 個が転移陽性であった。原発巣はly (一), v(一) でリンパ節転移を予想すべき所見は何も なかった．他の 1 例は $\mathrm{s}$ に発生した Isp で, $1.5 \mathrm{~cm}$ の tumor の頂点がわずかに陥凹していた，polypectomy 後の病理検查で宿凹部を中心に sm に中等度漫潤した 癌と診断された。わずかな tubular adenoma を併存す る高分化腺癌で，やはり ly (-), v (一)であった。し かし sm 浸潤した先進部で癌の組織型の分化度が著し く低下していたことを理由に追加手術を行った。切除 腸管に癌の遺残は無かったが，郭清したリンパ節 8 個 のらち，1個に転移を認めた. 両者とも 1 群, epicolic nodeの転移であった（表 7 ）。

\section{考 察}

大腸早期癌の治療方針で $\mathrm{m}$ 癌は local excision で 十分その根治性を保てるといらのが定説となってい る。それは Fenoglio ら ${ }^{6}$ の粘膜筋板でリンパ管は plexus を形成するが，それより表層でリンパ管を認め られないといら研究報告に負うところが多い，事実， 現在までに $\mathrm{m}$ 癌のリンパ節転移報告例はない。しかし $\mathrm{sm}$ 癌では $3 \sim 8 \%$ にンン゚節転移陽性の症例があ り，進行癌なみの外科治療を行うか， m癌に準じた治 療を行らか議論の分かれるところである7 目)．安富 $ら^{111}$ は, 721例の早期癌を集計し, 290例の $\mathrm{sm}$ 癌の5ち 23例， $7.9 \%$ がリンパ節転移陽性で，Ipの $6.2 \%$, Is の $11.3 \%$, IIa の $7.9 \%, \mathrm{IIa}+\mathrm{IIc} の 20 \%$ の転移率を認めた と報告している.

われわれの症例ではIIa+IIc など複合型の形態を 示した時は polypectomy などす困難で，委た全例が sm 癌であったので諸家の述べていると拈り進行癌と 同様の扱いが妥当と思われる. しかし今回リンパ節転 移を認めた 2 例はともに Isp で，有茎性 $\mathrm{sm}$ 癌の転移 率も決して無視でさない，今回の検索では癌の大きさ と sm 浸潤の相関は認められず，大きな腫場でもまず できる限り local excisionを行い深達度を確認すべき

表 7 リンパ節転移症例

\begin{tabular}{c|c|c|c|c|c|c|c|c|c|c}
\hline Pt. & 性 & 年 & 病変部位 & $\frac{\text { Cancer }}{\text { Tumor }}$ & 肉眼型 & 組織型 & Iy & v & sm & sm 浸潤部 \\
\hline K. K. & $\hat{\delta}$ & 48 & R. & $0.5 / 3.0 \mathrm{~cm}$ & I sp & well & - & - & + & 分化度低下 $(-)$ \\
\hline R. H. & $\hat{\delta}$ & 72 & S. & $1.1 / 1.4 \mathrm{~cm}$ & I sp & well & - & - & H & 分化度低下 $(+)$ \\
\hline
\end{tabular}


である， m癌の直腸切断術を施された 3 例のうち 2 例 は5 $\mathrm{cm}$ 以上の polypoid cancer, 1 例 $55 \mathrm{~cm} の$ tubulovillous adenoma 内の $0.5 \mathrm{~cm} の$ focal cancer で 肉眼的は 3 例とむIsであった。 その大きさ故に polypectomy なども困難であったと思われるが, over surgery を否めず，をず経括約筋的または経仙骨的了 プローチを試みるべきであった。

有茎性大腸癌に polypetomy を行って sm 癌と診断 された場合の問題であるが，大腸癌取扱い規約では原 則として追加切除を検討する必要があると記載されて いる，また，(1)明らかな脈管内癌浸潤，(2)低分化腺癌 あるいは未分化癌，(3)断端近傍までの massive な癌浸 潤といら所見が認められた場合は，転移の危険性が高 く腸切除を追加して行ら必要であるとしている。

1985年 4 月までに $\mathrm{sm}$ 癌でリンバ節転移を認めた症

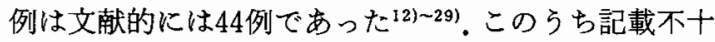
分なものを除外し，肉眼型，組織型，脈管侵襲につい て検討した。肉眼型の内訳は Ip 8 例，Isp 4 例，Is 12 例, IIa 5 例, IIa +IIc 11例, IIc 1 例で, 従来転移危 険率が高いとされていた IIa+IIc のみならず，Ip, Isp などの有茎性腫瘍が最近の症例の蓄積により増加し て，転移例全体で占める割合も決して無視できないこ とがうかがわれる，組織型では高分化腺癌23例，中分 化腺癌 8 例, 低分化腺癌 2 例, 本邦の低分化腺癌の症 例数が少ないことを考慮すればこのタイプの転移の危 険性惊高いといえる。しか高分化，中分化の分化型 腺癌が大腸癌の $90 \%$ 以上を占める日本の現状では, 組 織型を転移の危険度の指標とする有用性には疑問があ る。また ly (+) は18例, ly (一) は13例で, ly (-) でもリンパ節転移の危険性は $\mathrm{y}(+)$ とさほぼ変わり がないと思われる。

われわれの症例では $\mathrm{sm}$ 癌の 20 例中 6 例が $\mathrm{ly}(+)$,

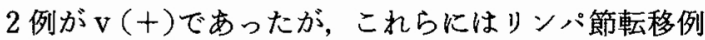
はなく，転移例は 2 例とも $\mathrm{ly}(-), \mathrm{v}(-)$, 高分化腺 癌であった. 今回 polypectomy 後 $\mathrm{sm}$ 癌之診断され追 加手術をした症例が 6 例あったが，これらは，(1) ly (t) or $\mathrm{v}(+)$, (2)浸潤先進部の分化度が低い, (3)切除 断端付近の浸潤が強いといら理由で腸切除術を追加し ている。この中で切除腸管に癌の遺残を認めたものは なく，浸潤先進部の分化癌が低くなっていた症例にリ ンパ節転移を認めた。この癌は表層の $\mathrm{m}$ は典型的な高 分化腺癌で，sm に浸潤するに従って腺管形成が之し くなり，充実性の増殖を示し中分化～低分化腺癌とい 学る形態を呈した(図 5 )。このような所見は従来のリ
因 5 HE 染色 $(\times 200)$ ，畽湯細胞は腺構造をつくらず 細胞異型著明。

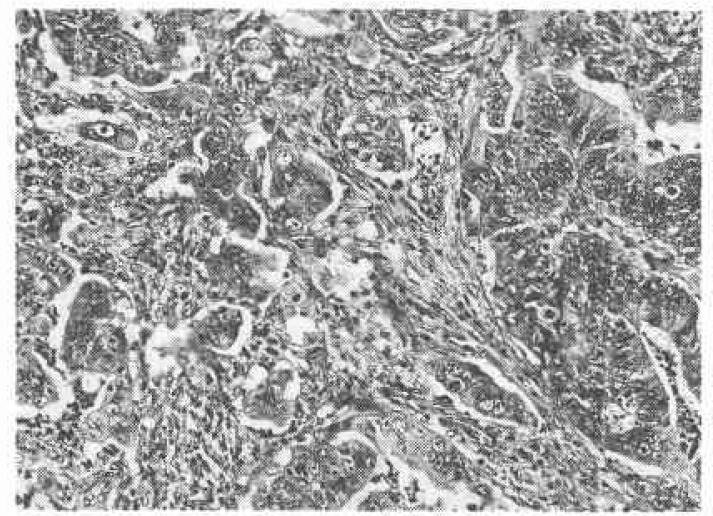

図 $6 \mathrm{HE}$ 染色 $(\times 180)$. 腫煌の一部が腺構造部を離れ 間質内に突出するように浸潤を始める。

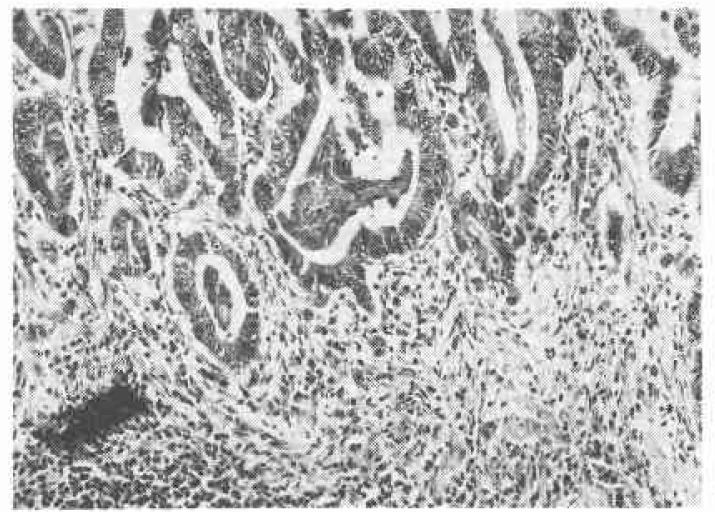

ンパ節転移の risk factorの指標にはなく注目したい。 も5 1 例のリンパ節転移例は villous adenoma に併存 する focal cancer で, 腫瘍頭部付近の粘膜筋板内でわ ずかに初期浸潤像を示すのみであった(図 6 )。癌は小 さく, 高分化腺癌で ly $(-), \mathrm{v}(-)$ と，リン八節転移 を予測させる所見は全くない, villous tumor は悪性度 が高く，癌のわずかな sm 浸潤でも転移の危険性が高 く,特別な扱いをすべきであるといわれている30131). 本 来 adenoma と carcinoma を区別する線引きは生物 学的には不可能であるとされていて，良性，悪性の区 分は臨床上便宜的に行っているにすぎないともいわれ ている、したがってこのような小さな癌の転移に遭遇 すると, villous tumor についてはわれわれが考光てい るよりもっと adenoma 側で carcinoma との線引き をして（病理形態学的にはともかくとして臨床的に）, 
全体を癌として扱ったほらが安全と思われる。すなわ ち villous tumor の sm 癌ではたと充転移の危険因子 がなくても積極的に major operationすべきであると 考克る ${ }^{211}$.

以上よりリンパ節転移を有する46例の $\mathrm{sm}$ 癌を検討 して，そのリンパ節転移の傾向を求めたが， local excision が絶対に安全であると断定できる条件はなく， sm 癌はすみやかに郭清を伴 5 major operation を追 加するのが最善と思われる。

最後にリンパ節転移の程度と郭清範囲について考察 する．自験例を含めて $\mathrm{n}(+)$ は46例で $\mathrm{n}_{1}(+)$ は 38 例 $(83 \%), \mathrm{n}_{2}(+)$ は 7 例 $(15 \%), \mathrm{n}_{4}(+)$ が 1 例 ( $\left.2 \%\right)$ 存在していた。以前は $\mathrm{sm}$ 癌で $\mathrm{n}_{2}$ 以上のリンパ節転移 は極めてまれと考兄られていたが，今回は 8 例 $17 \% に$ 認められ郭清範囲を $\mathrm{R}_{2}$ とすることの妥当性が示唆さ れた. 竹村 ${ }^{32}$ の行った Tc-99年利用したリンパ流の研 究より,リンバ管は必ずしも遂次的に末梢リンパ節 $\rightarrow$ 中間リンパ節 $\rightarrow$ 中枢リンパ節と通過するとは限らず, 末梢リンパ節（1 群のリンパ節）を介さないで，腸管 より直接中間リンパ節（2群のリンパ節）に向から流 れもあることが明らかになった ${ }^{33)}$. 形態的には 2 群り ンパ節だが機能的には 1 群のリンパ節が存在するため に，早期癌でも 2 群のリンパ節への転移，いわゆる跳 躍転移が認められる。結腸癌では $\mathrm{R}_{2}$ もしくは $\mathrm{R}_{3}$ の手 術はさほど障害を残すことなく行兄るが，直腸癌では 脱落する機能との兼祮合いが問題となる，直腸の進行 癌では内腸骨リンパ節，閉鎖リンパ節などの側方郭清 が求められる場合るあるが，今回集計した直腸の早期 癌で 2 群りンパ節転移例は上直腸リンパ節 3 例，中直 腸動脈根リンパ節 1 例と上方経路に多く, 症例もまれ なのであえて側方郭清まで行う必要はないと思われ る.

切除すべき腸管の長さについては，大腸癌取扱い規 約に従って, 前述のような理由から $\mathrm{R}_{2}$ 以上の手術を行 おうとすれば，同様に最低 $10 \mathrm{~cm}$ 以上(直腸の肚門側切 除範囲を除いて）の切除が必要といらことになる。し かしやはり Tc- $99^{\mathrm{m}}$ による観察では, 大腸のリンパ流は 強い中权指向性を示している。つまり支配動脈に沿っ た上行性の進展形式が主で，それに逆っての傍結(直) 腸リンパ節への水平方向の流れは少ない，転移陽性の 大腸早期癌で個々の転移リンパ節が少ない点を考慮に 入れれば，切除腸管の長さについては柔軟に考えて良 いと思われる。術中の肉眼的所見により過度のリンパ 節転移がないと判定されれば，その脈管支配を考慮し
て，可及的に機能を温存できるように切除範囲を決め て良いと思う。

\section{結語}

大腸の早期癌 49 例 50 病巣および文献上リンパ節転移 を認めた $\mathrm{sm}$ 癌47例について検討し，以下の結論を得 た.

1. 自験例では肉眼型が深達度と強い相関を示し, I

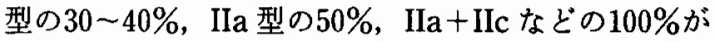
sm癌であった。

2. $\mathrm{sm}$ 癌の肉眼型, 病理組織所見より, リンバ節転 移の危険性を予見し治療方針を決定するのは不可能で あった。

3. $\mathrm{sm}$ 癌の治療はその肉眼型, 脈管侵襲の有無, sm 漫潤の程度にかかわらず, $\mathrm{R}_{2}$ の郭清を伴った major operationを行うべきである。

稿を終るにあたり，土浦協同病院，取手協同病院，太田綜 合病院，上尾中央病院の外科より貴重な症例を和借りでき たことに，謝意を表します。

\section{文献}

1）大腸癌研究会編：大腸癌取扱い規約．第 2 版，東 京，金原出版，1980

2）太田邦夫：早期大腸癌の定義について。臨外 $31: 13-15,1976$

3) Shatney $\mathrm{CH}$, Lober PH, Sosin H : Metastasis from apedunculated adenomatous colonic polyp with focally invasive carcinoma. Dis Colon Rectum 18:67-71, 1975

4) Shatney $\mathrm{CH}$, Lober $\mathrm{PH}$, Gilbertson $\mathrm{V}$ et al: Management of focally malignant pedunculated adenomatous colorectal polyps. Dis Colon Rectum 19 : 334-341, 1976

5）岡部 聡, 中島和美, 若山 宏汪か：珍しい発育形 態 $(I I c+I p)$ をした大腸早期癌の 1 例. Prog Dig Endosc $26: 342-345,1985$

6) Fenoglio CM, Kaye GI, Lane N : Distribution of human colonic lymphatics in normal, hyperplastic, and adenomatous tissue. Gastroenterology $64: 51-66,1973$

7) Morson BC, Bussey HJR, Samoorian S: Polycy of local excisicion for early cancer of the colerctum. Gut $18: 1045-1050,1977$

8）大腸繁男, 大見良裕, 辻仲康伸ほか：大腸早期癌 （とくに sm 癌）の治療方針. 医のあゆ 122： 549556,1982

9）高橋 孝：大腸早期癌の治療方針。胃之腸 15 ： 399-407, 1980

10）北條慶一：大腸早期癌の治療方針について，日本 大腸肛門病会誌 $28 ： 373-376,1975$ 
11）安富正幸：大腸癌手術における諸問題. 外科治療 47：199-206, 1982

12）北條慶一, 小山靖夫, 伊藤一二ほか：大腸の早期 癌. 癌の臨 $16: 228-232,1970$

13）土屋和弘, 山本恵一, 卜部美代志：早期值腸癌. 外 科治療, $14: 659-667,1972$

14）粕川剛義：大腸早革癌の臨床研究扰よび大腸癌の 病期分類についての考察. 日本大腸肛門病会誌 $26: 371-379,1973$

15）高橋 孝：早期大腸癌の遠隔成績. 臨外 31 : $751-756,1976$

16）第13回大腸癌研究会抄録, 主題 II：sm 癌のすべ て. 日本大腸肛門病会誌 $34: 251-271,1981$

17）落合浩平, 大㭷 弘：直腸癌の手術：第 III 報一早 期值腸癌の治療について一, 函舘医誌 $7: 3-8$, 1983

18）高島茂樹, 上村卓良, 片山外一ほか：大腸早期癌の 臨床病理学的特徵と治療方針について．日消外会 誌 $15: 1546-1552,1982$

19）小舘 史, 棟方昭博, 伊藤愛一郎注か：リンパ節転 移を認めた大腸 $\mathrm{sm}$ 癌の 1 例. 青森中病医誌 $29: 170-173,1985$

20）豊野 充, 鈴木清夫, 松本 繁注か：大腸早期癌手 術例の検討。日臨外医会誌 $43: 565-570 ， 1982$

21）加藤知行, 森本剛史, 山村義孝ほか：大腸早期癌の 検討一とくに治療方針について一. 日消外会誌 $16: 1968-1975,1983$

22）伊藤英明, 古賀 淳, 下田 淳ほ力：大腸早期癌の 治療方針。胃々腸 $15 ： 409-416,1980$

23）市川正章, 清水 豊, 田中正人：リンパ節転移を認
めた大腸 $\operatorname{sm}$ 癌の 1 例。胃と腸 $18: 824-825$, 1983

24）貝原信明, 木村 修, 古賀成昌：Virchow 転移を 来して死亡した有茎性直腸 $\mathrm{sm}$ 癌の 1 例. 胃と腸 $18: 840-841,1983$

25）大木繁男, 大見良裕, 土屋周二 : $\mathrm{ly}_{1}, \mathrm{n}_{1}(+)$ であっ た要有蒵性 S 状結腸 sm 癌の 1 例。胃之腸 18 ： $834-835,1983$

26）長谷川かをり, 鈴木 茂, 長廻 紜：IIc 型早期大 腸癌の 1 例。胃と腸 $18: 842-843,1983$

27）中尾恭輔, 山田達哉, 廣田映五：術前に sm 癌と診 断し穴た早期直腸癌の 1 例。胃と腸 $18: 844$ $-845,1983$

28）宮下 徹, 岩瀬孝明, 岩喬 : 直腸癌局所切除術 の選択基準. 外科治療 $48: 303-311,1983$

29）沢田俊夫, 吉田 誠, 中島利子：傍直腸リンパ管浸 潤が認められた massiveinvasive cancer の 1 例。 胃之腸 $18: 810-811,1983$

30）北條慶一：大腸の Villons Tumor，医のあゆみ $69: 102-104,1969$

31）丸山雅一, 佐々木喬敏, 横山善文：大腸早期癌の診 断に関する知見補遺一とくに診断基準の再検討お よびポリペクトミの諸問題一。胃と腸 15 : $375-391,1980$

32) 竹村克二, 金子慶虎, 高相 進注か：Tc-99m $v=$ ウムコロイドを用いた直腸リンパ流に関する研 究. リンパ学 $8: 171-174,1985$

33）高橋 孝：大腸癌リンパ節転移の実態と予後。医 のあゆみ $122: 590-595,1982$ 